HORIZON 8 (2) 2019 : I. Research : P. Špecián : 613-631

ФЕНОМЕНОЛОГИЧЕСКИЕ ИССЛЕДОВАНИЯ • STUDIES IN PHENOMENOLOGY • STUDIEN ZUR PHÄNOMENOLOGIE • ÉTUDES PHÉNOMÉNOLOGIQUES

https://doi.org/I0.21638/2226-5260-2019-8-2-613-631

\title{
PHENOMENOLOGICAL PERSPECTIVES ON ECONOMICS: SCHÜTZ VERSUS DÜPPE
}

\section{PETR ŠPECIÁN}

$\mathrm{PhD}$ in Economics, Assistant Professor.

Charles University, Faculty of Humanities.

15800 Prague, Czech Republic.

E-mail: specian.p@gmail.com

The article explores novel directions in the phenomenology of economics. It analyzes how the approaches of Till Düppe and Alfred Schütz, both inspired by Edmund Husserl, may shed light on the historical development of economics. I examine the substance and meaning of economics in the context of the forceful criticism of the whole discipline recently raised by Düppe. This examination uncovers important weaknesses and omissions inherent in Düppe's argument against the economists' scientific aspirations. The analysis of the social scientific endeavors by Alfred Schütz who develops a phenomenologically informed 'telescopic' concept of an ideal type is then shown to be a more fruitful and methodologically rigorous way towards understanding the developments within economics. The Schützian view permits us to see how abstract economic models originate in the experience of the life-world and are continuous with it. Accordingly, the historical development of economic science may be viewed as consisting from two broadly defined phases, where at first the formalism is steadily increasing (the 'zooming out' phase) and later the discipline converges back to context-specific empirical examinations (the 'zooming in' phase). A case study concentrating on the economic theory of politics illustrates that both the drive towards abstraction that has culminated around 1950s and the more recent 'zooming in' is methodologically legitimate from the phenomenological point of view. I conclude that economics has never been completely severed from the paramount reality of the everyday life and for decades the interconnection has been growing stronger by the day.

Key words: Alfred Schütz, crisis of science, formalism, historicism, life-world, phenomenology of economics, telescopic ideal type.

C PETR ŠPECIÁN, 2019 


\section{ЭКОНОМИКА В ФЕНОМЕНОЛОГИЧЕСКОЙ ПЕРСПЕКТИВЕ:}

\section{А. ШЮЦ ПРОТИВ Т. ДЮППЕ}

\section{ПЕТР ШПЕЧЯН}

Доктор экономики, доцент.

Карлов Университет, Факультет гуманитарных дисциплин. 15800 Прага, Чешская Республика.

E-mail: specian.p@gmail.com

В статье рассматриваются новые направления в феноменологии экономики. Предметом анализа становится то, каким образом проекты Тилля Дюппе и Альфреда Шюца, инспирированные Эдмундом Гуссерлем, позволяют пролить свет на историческое развитие экономической науки. Я рассматриваю сущность и значение экономики в контексте той резкой критики экономической науки в целом, которой ее недавно подверг Дюппе. Этот анализ вскрывает важные недостатки и упущения, присущие аргументации Дюппе, направленной против научных притязаний экономистов. Анализ специфики социальных наук у Альфреда Шюца, разрабатывающего феноменологически преобразованный, «телескопический» концепт идеального типа, раскрывается затем как более продуктивный и методологически строгий путь к пониманию тенденций экономической науки. Подход Шюца позволяет нам понять, как абстрактные экономические модели возникают из опыта жизненного мира, не утрачивая с ним контакта. Соответственно, историческое развитие экономической науки может рассматриваться как состоящее из двух фаз в широком смысле слова. На первой формализм постепенно нарастает (фаза «отдаления»), на второй экономическая наука возвращается к конкретным эмпирическим исследованиям (фаза «приближения»). Кейс-анализ, концентрирующийся на экономической теории политики, служит иллюстрацией того, что как тяготение к абстракции, достигшее апогея в 50-х годов XX века, так и более современная тенденция к «приближению» методологически легитимны с феноменологической точки зрения. На основании проведенного анализа делается вывод, что экономика никогда не была полностью оторвана от изначальной реальности повседневной жизни и на протяжении десятилетий взаимосвязь экономической науки и повседневности становилась прочнее день ото дня.

Ключевые слова: Альфред Шюц, кризис науки, формализм, историцизм, жизненный мир, феноменология экономики, телескопический идеальный тип.

\section{INTRODUCTION}

On the outset of the new millennium, in one of the leading economic journals, Edward P. Lazear has published a lengthy article named Economic Imperialism that commemorates the success of economics in the conquest of neighboring disciplines ${ }^{1}$.

1 The intellectual father of economic imperialism is Gary Becker (1978) who won a Nobel Prize for his study of topics outside the traditional domain of economics. 
He describes the relative advantage of economics against other social sciences in the following fashion:

The power of economics lies in its rigor. Economics is scientific; it follows the scientific method of stating a formal refutable theory, testing the theory, and revising the theory based on the evidence. Economics succeeds where other social sciences fail because economists are willing to abstract. (Lazear, 2000, 102)

Does this pompous claim ring true? Many people, both in economics and outside, share doubts about the descriptive precision of Lazear's statement. Among them, Till Düppe (2011) has composed one of the strongest condemnations of the scientific aspirations economists traditionally have. Düppe's perspective is novel in employing Husserl's phenomenology to support his argument. In his view, the economists' effort to achieve the status of genuine science was driven by the desire to shed 'the economic suspicion' that they only represent partial interests. Being genuine scientists offered an opportunity to speak in a neutral, disinterested voice. However, the price of 'scientification' of economics was the loss of its relevance and meaning, according to Düppe. Economic theory may have achieved substantial rigor. However, it is a rigor mortis-empty and completely detached from the phenomena of (economic) life, from the life-world. The whole scientific program of modern economics is, in Düppe's eyes, beyond redemption. Scientific economics cannot be reconnected with the life-world. The only way forward is to disband the departments of economics. The people, who call themselves economists today, would find their place in other departments or think tanks, where they may rediscover the lost meaning of their work after shedding their distanced attitude.

The contrast between Lazear's and Düppe's view is rather astonishing. On the one side, triumph and optimism: economics has been reaping one success after another, gaining prestige and esteem, all thanks to its scientific rigor. On the other side, complete condemnation: scientific program in economics has been an utter failure, it has burned out, and the discipline is ready to be disbanded for the sake of more meaningful efforts.

My aim in this essay is to suggest a middle road between the two extremes. Economics is neither overwhelmingly successful nor an embarrassing failure. Its scientific accomplishments can be easily overstated, but the strive for rigor has not been a disaster either. What Düppe interprets as a self-destructive escape from the life-world, can be viewed through the more charitable lens as an immensely intellectually fruitful, even if in some important ways unsuccessful, search for general laws of human action. The relative lack of success in this search, far from marking the 
beginning of protracted death throes of economics, is a hallmark of its return from the Olympian heights of abstraction closer to the life-world ${ }^{2}$. Making my case, I will suggest possibilities of providing a phenomenological analysis of what economists do that differs from Düppe's account. This analysis will not follow in the footsteps of Edmund Husserl's work The Crisis of European Sciences, but rather in those of Phenomenology of the Social World (1972 [1932]) by Alfred Schütz who undertook the most comprehensive and influential phenomenological analysis of the social sciences and their methodology.

\section{WHAT IS ECONOMICS?}

Extensive developments took place in economic thinking and in thinking about economics since Adam Smith's foundational piece An Inquiry into the Nature and Causes of the Wealth of Nations published in 1776. If we ask what economics is, no one answer can capture all the shapes and shifts of economics in more than two centuries. Nevertheless, the most famous and frequently quoted definition has been provided by Robbins (2007, 15): "Economics is the science which studies human behavior as a relationship between given ends and scarce means which have alternative uses." The scope thus delimited can support the so-called 'economic imperialism' which is a label for the ambitions of economists to conquer other social sciences by either replacing their practitioners or forcing them to accept the economic methods (Lazear, 2000, 104). Robbins's definition supports such imperial ambitions once we recognize time as one of the 'scarce means.' Because time available for any action is always limited, any purposeful human behavior is a subject of study of economics. Nevertheless, the definition feels incomplete-how is economics different from, say, sociology, if it has virtually the same domain? Robbins needs to be supplemented.

The difference between economics and other social sciences is not in what it studies, but how. Gary Becker (1978) famously brings this 'how' down to three cornerstones of the economic approach to the study of human behavior. In his view, the approach is constituted by the assumptions of maximization, market equilibrium, and stable preferences. Whatever an economist studies, be it a market for cucumbers or criminal behavior, these three assumptions constitute his point of departure. It is no coincidence that they also allow for an easy formalization of the decision-making

2 The 2017 Nobel Prize for Richard Thaler for 'humanizing economics,' or even for 'killing homo economicus,' as some have put it, is yet another important milestone in this development. 
problems and their translation into the language of cost-benefit analysis. By them, one can tell an economist from any other social scientist dealing with the same subject of study. In Lazear's (2000) article 'stable preferences' have been replaced by 'efficiency.' The idea of a specific economic approach survives untouched, however.

Let us accept these as preliminary, not consensual but still viable answers to what and how questions. What human behavior does economics study? Any. As long as it can be seen through the teleological lens of means-ends relationship, i.e., if it can be perceived as action. How does economics study human action? It starts from basic assumptions (or principles), deduces their implications, builds a model of the situation. The principles are considered central and only around them one can weave the fabric of less general working assumptions and hypotheses based on the nature of the scientific problem at hand. When building a model, one may wonder whether the agents act $a$ s if they maximize profit, revenue or something else, and what constraints on their actions are present in the given situation. However, one may not doubt that their actions can be modeled as maximization of something and that there are some constraints.

Nevertheless, the fundamental cause of Lazear's and Düppe's strongly differing views on economics is deeper than what and how do the economists study. We can only find it at the level of the meaning of scientific economics. Düppe $(2011,33)$ revives Husserl's criticism of detachment of modern science from the life-world: "As the correlate of life-care, the life-world is what gives weight to meaning. It grants affective weight to an intellectual act..." Economics may seem successful; it 'passes the market test' as Lazear $(2000,104)$ puts it. However, if it has lost its connection with the life-world, it finds itself ultimately without meaning, and its fate is to wither and disappear. It is Düppe's central claim that the loss of meaning has already happened because the life-world has been forgotten in economics and replaced with formal models, notably the general equilibrium model, that ultimately do not refer to anything. Economics is "plagued by a desperate search for novelty" (Düppe, 2011, 13) which may deceive an onlooker into mistaking the decline for flourishing. However, the demise of the whole discipline is both desirable (Düppe, 2011, 216) and highly probable (if not inevitable) as the search for novelty slowly undermines the collective identity of economists. Today, they are only united in a negative fashion, i.e., by the 'dead' neoclassical theory that all of them criticize ${ }^{3}$.

3 Dissolution of economics would also mean general resignation on scientific approach in all social discourse (Düppe, 2011, 12-13). 
Because the idea of the crisis of meaning is central to Düppe's account, let me examine it in more detail. What is the meaning of economics? This is a rather complex question that can be answered at three different levels: the personal meaning for a working economist, the pragmatic meaning for a layman who can be a proverbial 'man in the street' or a public official eager to obtain some policy recommendations, and arguably also the general meaning for 'society' or even 'humankind.' Here, Düppe's argument becomes quite nebulous. His book invites the reader to reconsider "the historical conditions under which economics could be meaningful” (Düppe, 2011, 16). Well, meaningful to whom?

Partly, it is the personal meaning that is at stake. "What moves economists? What keeps them exercising their profession?” asks Düppe $(2011,29)$. This question is, of course, rather important. Quite certainly, however, more economists would talk about intellectual curiosity, professional esteem, the pure pleasure of solving difficult puzzles, or perhaps just 'a way to make money,' than about a "culture of distrust," or "social anxieties" (Düppe, 2011, 3-4), if asked ${ }^{4}$. Following Husserl, Düppe talks about meaning in a different sense of the word as well. Lack of meaning in economics is also criticized based on the alleged absence of practical relevance of economic theories. On many occasions, be it a debate between capitalism and socialism or more recently the Great Recession, economists disappointed the laypeople by their inability to predict the future or to agree on practical recommendations. In this sense, Düppe $(2011,11)$ equates meaningless with useless in practice: "the continuous frustration of the demand to produce relevant knowledge." Practical relevance is indeed a somewhat painful spot for economists. They often quote the prediction commitment ${ }^{5}$, especially when challenged about the relevance of their science by outsiders, but their track record is far from spotless. Still, however embarrassing the low reliability of economic predictions may be concerning the public relations, it is difficult to see why it should be necessarily destructive with respect to the meaning an economist herself finds in her work. Commitment to prediction can be an official stance, but it is probably not what gets most practicing economists out of bed in the morning.

The nature of the motivation of an economist is historical (Stigler, 1983). There is a strong continuity in the discipline: what constitutes an attractive 'problem at

4 Düppe always sees economists as indecisive, evasive, pessimistic, useless, in crisis, etc. There is not much empirical support for this view that would go beyond anecdotes, though.

5 The prediction commitment was most famously elaborated by Friedman (1953). 
hand' is determined by what has been achieved so far ${ }^{6}$. Due to the general publish or perish attitude, a working economist must stay on the research frontier as it is in the moment when she starts her career. Being an economist at any point in time means doing what the other economists are presently doing and what they respect. To earn esteem and influence, or even just to survive in the profession, one needs to impress the others when playing by the presently established rules. Only then she can try to change the rules themselves if she finds that desirable ${ }^{7}$. Any established discipline works in such a way, sociologically taken.

Here we approach the general sense in which one might talk about meaning. Düppe's book is a phenomenological genealogy of economics, not a chronicle of economists' motivations and their relations to the lay public. Düppe $(2011,34,56)$ follows Husserl in claiming that "[a]ll intellectual accomplishments such as theories, models, concepts, hypotheses and so on, are intelligible only regarding the concrete history of sense that has led to them," or that "...modern science is carried by the transcendental dream of 'mathematical science." "

The general sense in which meaning is used here is more fundamental than the others. Some economists may have personal doubts if their work is meaningful, laypeople's trust in economics may be shaken, but ultimately it is a more profound loss of meaning of the whole discipline that is the most important for Düppe. He talks about the irresistible lure of mathematical formalism in the economic theory that draws it always further from the genuine experience of the life-world and increases the estrangement of economics (Düppe, 2011, 48, 61).

The propensity towards formalism is impossible to deny as it is inherent to the prediction commitment. To predict anything, one needs to search for regularities and trends that could be generalized beyond the scope of a unique historical moment. That is why economic science has been driven by the search for general laws of human action. Economics is officially supposed to enhance people's abilities to manage scarce resources. The discovery of general laws of action would establish permanent knowledge whose relevance exceeds any historical context. This quest motivated climbing the Mount Abstract using tools of mathematical formalism. Although the high hopes invested in the quest have abated, commitment to

6 Kuhn (1996) is obviously a relevant source here.

7 Richard Thaler's Misbehaving (2015), an autobiographical account of the history of behavioral economics, is quite illustrative in this regard. 
prediction is still used to claim respect towards economics among the decisionmakers and to fend off the possible suspicions regarding economists' political bias.

Be it as it may, when talking phenomenologically about the general meaning, one needs to be specific about for whom it is supposed to mean something-it cannot float free. Is it something else than a personal and pragmatic meaning? Düppe's account remains enigmatic in this regard. The primary object of his interest lies with the economists. Despite some claims to the contrary (Düppe, 2011, 212), the main argument of Düppe's book is not a descriptive claim that economists do not find meaning in their work. That would call for a therapist instead of a phenomenological philosopher. The argument is that finding any meaning in scientific economics is impossible due to its formalism: “...I argue that whatever economists want to be, say, or explain, seeking scientific authority is of no help for their expressive life and lowers their intellectual sensibility" (Düppe, 2011, 17).

Instead of trying to set the personal, pragmatic, and general meaning of economics apart in a more detailed fashion, I want to dedicate attention to this more pressing issue. Whatever the precise relationship between the aspects of what a 'meaning' may stand for, if formalism is indeed a destructive phenomenon, economics is certainly doomed. For economics, in all its shifts and shapes, is identified chiefly by abstract formal theory. Thus, there is an urgent question to ask: Are Düppe's phenomenological conclusions valid?

\section{PHENOMENOLOGY OF ECONOMICS: THE SCHÜTZIAN VIEW}

Düppe's phenomenology of economic science relies heavily on Husserl's account provided in The Crisis of European Sciences. The main problems of Düppe's argument follow from the fact that he does not come to terms with Alfred Schütz's careful elaboration of how Husserl's phenomenological method could and should be used in the social sciences. Husserl himself concentrated on problems of natural sciences. It was Schütz who thought most deeply about the specifics of the scientific study of the social world and social action and won acclaim among the social scientists. For all his effort and influence, Schütz has earned only one passing remark and zero quotes in Düppe's book. Such omission is quite unfortunate because Schütz

8 This means leaving aside the predictive failure per se. Yes, predictive failures should give us a pause, when we are considering practical relevance of economics. But such an argument can be made on distinctly non-phenomenological ground as well (Rosenberg, 1994, 2005). 
and Düppe share the same concern', and Schütz's findings conflict with Düppe's both in the question of meaning and the question of formalism.

From the phenomenological standpoint, any claim to 'objectivity' needs to be traced back to the original givenness of phenomena in individual consciousness. Any knowledge, including scientific knowledge, therefore must be, at its root, grounded in both individuality and subjectivity. Meaning also cannot be independent of consciousness. For Schütz, the question of meaning is of primary importance in the context of (social) action. However, the sense in which Schütz uses the term is much less dramatic than Düppe's. Individuals always attach meaning to any acts of consciousness they become reflectively aware of ${ }^{10}$. Actions are a specific subset of these. They are characterized by being based upon a preconceived project. In little everyday routines as much as in grand life-plans an individual's actions are always connected with subjective meaning. The main problem of social action and social science is the reconstruction of this subjective meaning by an observer (Schütz, 1972, $31 \mathrm{ff}$.). Even though one may face trouble recovering the 'correct' meaning, it is certain that it exists: a 'meaningless action' is an oxymoron. In this trivial sense, it is without a doubt that economists find their work meaningful as far as it consists of reflected conscious experience.

This answer is, of course, a bit of a sophism. Düppe does not doubt that economists act when they do economics. He worries about their "expressive life" and "intellectual sensibility." However, these topics are perhaps beyond what Schütz would consider a subject of phenomenological study. His criticism of some aspects of later developments in transcendental phenomenology seems to suggest as much (Schütz, 1975, 83-84).

There is still a common ground though. The expressive life, and the like, is at stake by Düppe, because of the disconnection of economics from the life-world through the means of formalization. This topic is one about which Schütz has a lot to say because the connection between the things, as they are primordially given to consciousness in their 'tangible presence,' and their abstract scientific models is one of the problems to which he has dedicated his intellectual career.

Schütz cannot overlook the importance of the relatively anonymous way in which the 'social forces' work. Not only in social science but also in everyday social

\footnotetext{
9 "Such is the concern of a phenomenology of science: it points out the difficult relationship between modern science and its experiential reality." (Düppe, 2011, 11).

10 “...meaning is a certain way of directing one's gaze at an item of one’s own experience.” (Schütz, 1972, 42).
} 
action we often do not deal with the others face to face and have only an abstract idea about who they are and what they intend. We may suspect personal agency behind, e.g., price movements, but we still do not directly experience a particular alter ego in action. Schütz (1972) subsumes these mediated social relationships under the labels of Mitwelt (the world of contemporaries) and Ihreinstellung (they-relationship). The absence of a face-to-face encounter with an alter ego whose actions exert influence upon us is the fundamental feature of the world of contemporaries. The alter ego in the world of contemporaries is not tangibly given; it is only suspected, lurking behind the horizon. Mitwelt is strictly opposed to the Umwelt (directly experienced social reality) where the other person is present 'face to face' in his living body (Leib). Here, our streams of consciousness can be aligned in experiencing simultaneously together (we-relationship). Therefore, the contrast between Mitwelt and Umwelt conspicuously brings up the issue of a difference between the immediate experience of reality itself and its derivative reconstruction as an ideal type.

An ideal type, the central concept of Weberian understanding sociology, has been adapted by Schütz for his phenomenological approach. Construction of ideal types is a necessary precondition of social action and its social-scientific analysis. The richness and incessant flow of consciousness are only graspable schematically and never in full. The process of construction of an ideal type proceeds by unifying the repetitive structural aspects that the reflective gaze identifies in the stream of consciousness. It allows us to 'fixate' the features we consider to be decisive and to emphasize the salient components of the otherwise inexhaustible diversity of individual phenomena. The typification may happen 'naively,' even unnoticeably, in the course of everyday life, or it may be a result of exacting intellectual labor of a scientist ${ }^{11}$. One way or the other, in a social context, it gives us the measure of understanding of other people's actions even where we cannot experience Umwelt together (Schütz, 1976a, 37-53).

Typification intensifies as we move to a higher level of abstraction. Schütz's concept of anonymity characterizes the gradual loss of experiential content in the increasingly abstract ideal types. Types may be anonymous to different degrees. In daily life and even more so in science, typification shields us from being flooded by details that would prevent orientation in the world:

11 The crucial difference between social and natural science is that a natural scientist builds her constructs afresh (first order constructs). A social scientist must base her types on the preexisting 'common-sense' typification of the naive agents in the social world (second order constructs) (Schütz, 1974a). 
[Typification] means the transformation of an uncontrollable and unintelligible world into an organization which we can understand and therefore master, and in the framework of which prediction becomes possible. (Schütz, 1976b, 71)

In the world of contemporaries, course-of-action ideal types and personal ideal types replace the living presence of an alter ego. The roots of these types can be traced to Umwelt, but they have lost the richness of the tangible presence of the things themselves, although in different degrees.

It is true that scientific attitude to the life-world is not quite the same as natural attitude. Non-scientific ideal types often arise spontaneously, without critical reflection, and are subject to frequent revisions. They do not form a coherent 'global' system. Nothing close to global coherence is necessary for successful everyday social action. Where the natural attitude is pragmatic in its interest, scientific attitude is cognitive (Schütz, 1974b, 245-259, 1976b, 69). It is an attitude of a lone unbiased observer who detaches himself from his biographical situation. Science is always empirical in the broadest sense of the word, but the scientific statements are only those that are free from the particular time-space of a singular experience and claim intersubjective validity for everyone. Scientific exploration is guided by an ideal of inner consistency and permanent, general knowledge. The concepts of the social sciences must be relatively anonymous, i.e., relatively empty. Exercising typification, the social scientist changes actors of the natural world into idealized puppets that are entirely in his power and fully transparent to him (Schütz, 1976b). Still, it is important to point out that although the scientific attitude may be more disciplined, it is also continuous with the common-sense typifications.

Schütz's analysis undermines Düppe's argument that formalism is the ultimate problem of economics (and science more generally). Düppe $(2011,53)$ tries to make his argument viable by emphasizing the difference between formalism and generalization: "While generalizations are only general as long as one retains the impression of the particular, and is thereby able to 'return' to it, in formalizations one learns to neglect the concrete." It is important to point out that the use of mathematics is a notable case of formalization, but it is not a necessary condition for its existence. Logical deduction and other types of highly abstract reasoning also count as formalism (Düppe, 2011, 60). Be it as it may, a distinction in kind between generalization and formalism is difficult to maintain. Is there indeed a discrete point at the scale of abstraction between the Umwelt and pure mathematics where generalization abruptly switches to formalization? Schütz's detailed examinations 
have never established the necessity of a presence of such a breach in the fluent scale of different degrees of abstraction.

At the same time, Schütz is not dismissive about the possibility that science will tear itself apart from the life-world. However, in his view, the situation is not quite as dire as Düppe would have it. Not even in economics. True, the scientific ideal type is a construct created in an 'unnatural,' rigorous way that may include formalization. It abstracts from all components of behavior that transcend the type. The method of deliberate 'cleansing' or 'purifying' the structural aspects of conscious experience to solve a social-scientific problem at hand does not have to rip the ideal types away from the life-world though. A scientific ideal type can be highly anonymous compared to the constructs used by naïve agents in their everyday life, and yet maintain continuity with them. Prendergast $(1986,16)$ talks of the "telescopic view of the ideal type" to capture this continuity. The ideal types can be less anonymous ('zoomed in') or more anonymous ('zoomed out'), but as far as they want to maintain the connection with the paramount reality of social action, abstraction must be a continuous variable.

Schütz (1976b, 85-88) ultimately captures his normative stance on the methodology of the social sciences in postulate of subjective interpretation and postulate of adequacy that should guarantee that the models, even if highly abstract, have a phenomenologically sound foundation. The former postulate requires the social scientists to hold to methodological individualism. Their models need to be based on an ideal type of an individual agent's mind. The latter postulate requires that the ideal-typical construction used in the scientific model predicts actions that are understandable to the actor himself as well as to other naïve agents within the life-world ${ }^{12}$. Now, seeing through the lens of Schütz's methodological postulates, does economics pass for success? Some general observations are due.

Firstly, even a very high level of abstraction and mathematical formalism is not unacceptable for Schütz if one can find an intuitively persuasive model of an individual mind in its core. In economics, the prominent case is the much discussed and much criticized ideal type of homo economicus. It is a type of maximum anonymity which transcends any particular situation. Nevertheless, it can still be explained in an intuitive way to people without economic training as any teacher

12 There is also a postulate of rationality which includes three additional requirements: i) compatibility of the model with the principles of formal logic; (ii) clearly defined concepts; (iii) scientifically verifiable assumptions. However, this postulate stands aside of the main argument of this paper. 
of introductory economics would confirm. Homo economicus is not alien and irredeemably detached from the lifeworld. It only cleanses a personal ideal type of a purely goal-oriented agent from the layers of biographical and situational context under which it usually remains hidden in our casual thinking about action.

Secondly, Schütz's postulates do not prevent large-scale 'imperialist' ambitions. Schütz $(1976 \mathrm{~b}, 87)$ gives the following advice to a practicing economist:

Build your ideal types as if all actors had oriented their life-plan and, therefore, all their activities to the chief end of realizing the greatest utility with the minimum of costs; human activity which is oriented in such a way (and only this kind of human activity) is the subject matter of your science.

At first sight, such advice may seem conservative. Upon closer inspection, however, it becomes clear that any human behavior that can be perceived as a choice between mutually exclusive alternatives can also be described using costbenefit analysis. Well, at least as long as one accepts a subjectivist view on costs and benefit, which is nevertheless far from incoherent with the phenomenological method. Therefore, it is possible to take Schütz's approach as far as Gary Becker, Edward Lazear, or any other 'imperialist' is willing to go. In this context, Knudsen (2004) even ranks Schütz as one of the conventionalist methodologists who oppose realism in economic theory.

Thirdly, using the telescopic view of an ideal type, we can interpret the history of modern economics as consisting of two major phases. The period between Adam Smith and the heyday of formalism is prevailingly the 'zooming out phase' where more and more historical details were being shed from economic models until just the ultimately anonymous structure, the skeleton of human action has remained. The opposite development, the 'zooming in phase' marks the (re)introduction of insights of other social sciences into economics. More and more institutional and psychological details are considered relevant in the economic profession ${ }^{13}$. It became apparent that too little about human action can be predicted using the bare skeleton only: 'historical,' situational details constitute the flesh and blood that improve the practical relevance of the models and bring them closer to the life-world. More and less anonymous ideal types are however not detached from each other.

13 When the leading behavioral economists (Ashraf, Camerer, \& Loewenstein, 2005) praise Adam Smith for his prescience, it is one of the signs of this return. 
Is Schütz's or Düppe's phenomenology of science a better guide to the understanding of economics and its development? Schütz's treatment surpasses Düppe's in both its clarity and methodological rigor. It does not rely on an ambiguous treatment of different senses in which economists' work may be meaningful that often borders on either psychoanalysis or normativity, neither of which has phenomenological support. It also does not require postulating an arbitrary breach in the scale of abstraction where suddenly a connection with the life-world must be cut off.

That is not to say that one cannot conduct social science in such a fashion that disconnects it from the social action and its subjective meaning. However, economics is not necessarily guilty by this. One may even suspect that its commitment to methodological individualism and methodological subjectivism makes it less prone to such mistakes than social sciences that treat 'social facts' in a holistic fashion.

To conclude, a closer inspection uncovers that economics shows no signs of inevitable decay, and no fundamental paradigm shift is at sight. Economics returns to many aspects of historicity that were once discarded during the search for the timeless general laws of human action. However, it does not fall back on them in desperation. It returns more organized, more systematic, and more informed about what questions to ask. The long 'detour' into abstraction was not a waste of time and effort. The last section provides a brief case study of how formalism has informed and motivated the relatively recent 'zooming in phase' in the development of economics.

\section{APPLICATION: AN ECONOMIC THEORY OF DEMOCRACY}

Although economics has been close to politics from the outset, many decades of development in economic thought were necessary before any comprehensive economic analysis of politics could be provided. Anthony Downs's (1957) book An Economic Theory of Democracy is the first attempt to achieve a thorough explanation of the democratic process through the lens of the economic theory. The text is valuable for us because it represents an example of highly abstract, formalist reasoning that, however, keeps in line with Schützian methodological postulates and also clearly motivates the successive zooming in.

Downs begins his analysis by building an abstract model of a 'rational political man,' a homo politicus. It is a person "who moves toward his goals in a way which, to the best of his knowledge, uses the least possible input of scarce resources per unit of valued output." (Downs, 1957, 5). In order to replace a living consciousness, which 
is intractable, by a personal ideal type-an anonymous, transparent puppet-the goals also need to be specified. Here, Downs $(1957,7)$ postulates that in democratic politics, a rational individual wants to select a government. Setting this goal sidelines other possible goals, like voting a certain way to please one's significant other or to conform with one's reference group, as it serves to transcend a biographical situation of a particular individual towards the general representation of human action in a setting of democratic politics. In other words, Downs (1957, 7-8) 'zooms out,' fully aware that his homo politicus "remains an abstraction from the real fullness of the human personality" and that such an "artificial man" may act differently from the flesh and blood individuals in the paramount reality of the life-world, which he calls simply "the real world."

This line of argument is important here for several reasons. First of all, it is crucial that it does not represent an outlier within economics, i.e., some heterodox, or even heretical, attempt to smuggle elements of phenomenologically informed methodology into economics, but a mainstream text that elaborates a fairly straightforward application of the standard economic theory. The only difference from the hallmarks of mathematical formalism like Kenneth Arrow's texts from the same period is that it relies on the use of natural language only occasionally supplemented with equations. Even so, it openly utilizes the fruits of mathematical economics, for example, Arrow's (1951) definition of rationality, and qualifies as 'logical formalism' excoriated by Düppe.

At the same time, it is remarkable how closely Downs's methodology corresponds with Schütz's methodological requirements. The postulates of subjective interpretation and adequacy are both observed. Methodological individualism is the gold standard of economic method and Downs duly constructs an ideal type of a representative agent's mind right on the outset of his analysis. The transparency of the ideal type is guaranteed by the rationality requirement that makes actions consistent with the goals-to-be-achieved, and by setting a goal of the political action. Concerning the adequacy postulate, it is essential that the goal of selecting the government is highly intuitive and it fits the way how people tend to understand their actions in the area of democratic politics.

So much for the accusation that formal reasoning has to be severed from the life-world and therefore meaningless. There is, however, another point to make. Above, I have claimed that highly abstract theories working with ideal types of the greatest degree of anonymity also have motivated 'zooming in' of the more recent economic research. To see the roots of this development, we need to follow the 
path of Downs's deductive reasoning for a couple more steps. Perhaps the most famous problem Downs (1957, Chapter 13) uncovers has been named "a paradox of voting." A rational individual who weighs costs and benefits of different alternatives decides not only for whom to vote, but also if she will bother voting at all. Given the negligible probability that a single vote will be decisive in democratic elections, even large expected benefits from the victory of the preferred candidate, party, or proposal need to be heavily discounted. Because the preferred alternative will in all likelihood win or lose no matter whether the given individual will decide to cast her vote, the benefits of voting (when seen from Downs's perspective of trying to select the government) are essentially zero. At the same time, the costs of voting, even if considering just the possibility that one will be hit by a car on the way to the polls, are greater than zero. As far as such a situation persists voters should abstain if they are rational. However, people do participate in democratic elections in great numbers.

The paradox of voting, a glaring anomaly in the rationality-based approach to human action, has attracted much attention ${ }^{14}$. Some critics even see it as a leading example of the inadequacies of the whole economic way of looking at human action (Green \& Shapiro, 1994). Such broad-ranging skepticism which would perhaps be in line with Düppe's views goes too far, however. It has been shown empirically that the theory correctly predicts marginal changes in voters' participation, if not its overall level (Dowding, 2005). In its limited precinct, it is quite successful. The paradox only means that we cannot expect too much from an approach that deals with perfectly anonymous puppets instead of actual living consciousness. The most we can do, if we consider the results unsatisfying, is to zoom in lower on the scale of abstraction. The living consciousness as such is forever beyond reach, but situational, biographical, and historical context may not be.

Zooming in is exactly the reaction the paradox of voting has elicited in much of the subsequent literature on the topic. Together with numerous other anomalies uncovered on the highest level of abstraction in works of the formalist economists, it helped to open new avenues in research that ultimately bring the economic profession into much closer contact with the historicity of the life-world: In what contexts is it

14 Downs himself downplays his results with an ad hoc speculation about utility of supporting democracy. That is a completely arbitrary solution, though. If it were accepted that paradoxes of human action can be solved in such a casual manner, the separation of economic thinking from the paramount reality of the everyday life would indeed be inevitable. 
adequate to postulate the agents' goals in line with narrow self-interest? Are there predictable triggers that influence people's interpretation of a given situation? Are there situations where even the mild and intuitive requirements of instrumental rationality get systematically violated? How does a particular sociological or psychological context of action modify its course? These are the questions examined by the new specializations like behavioral, experimental, or institutional economics. The growing share of these disciplines on the Nobel Prizes in economics proves their mainstream acceptance.

When today's heirs of Downs's research of democracy conclude that we need to search for ideal types with a sufficient degree of predictive power on a much lower level of anonymity than Downs intended (Achen \& Bartels, 2016), they do not state the obvious. The zooming in has been motivated and directed by the formalists grand search for the general theory of human action. Examination of the precise meaning and bounds of rationality has rigorously shown the limits of the general theory and, at the same time, established a unifying reference framework for work at lower levels of abstraction. Only continuous effort that was driven by the disconcerting results of the models using fully anonymous ideal types brought about results that may substantiate such conclusions. In the end, it is Anthony Downs, and other formalists like of him, whose work has motivated economists' return closer to the life-world.

\section{CONCLUSION}

This essay treads in a dangerous territory. It tries to fit the immensely rich and diverse scientific enterprise of modern economics with all its interconnections to other social sciences in a few simple schemata. Still, I believe that I have provided grounds for skepticism regarding far-reaching and seemingly devastating criticisms like Düppe's (2011). It is true that economics is abstruse on occasion, it sometimes overuses mathematics, its practitioners show undue self-confidence from time to time, and the predictive success of general theories is limited.

Nevertheless, the two hundred years' worth of economics has not left us emptyhanded. Driven towards rigor and abstraction, the economists have meticulously examined the logic of rational action and its implications for an abstract 'economy.' If we accept Alfred Schütz's findings, this endeavor was far from methodologically illegitimate, as seen from the phenomenological perspective. I have tried to illustrate as much on a case study of Anthony Downs's economic analysis of democracy which counts as one of the immortal classics in the economic profession. 
It is true that many of the formal results were either negative or not robust with respect to frequently occurring type-transcending behavior. They do not, by themselves, have sufficient predictive precision to be immediately practically useful. Still, even if one was ready to believe that this constitutes a failure of the formalist program, the failure was not barren. It helped to establish a common language of economics and a common set of principles of economic thinking. It also motivated the return from the heights of abstraction closer to the life-world. Economists and other social scientists come back to it wiser and more willing to cooperate-they still haven't solved many pressing problems of the social world and social action, but they have a much clearer about what are the right questions to ask and how to import findings from one discipline to another.

Idealized model worlds inhabited by artificial puppets are inevitably more anonymous than the Umwelt. However, it does not mean that they cannot inform us about how we can try to improve our understanding of the complex social reality that shapes our lives.

Acknowledgements. This publication was supported by The Ministry of Education, Youth and Sports-Institutional Support for Long-term Development of Research Organizations-Charles University, Faculty of Humanities (2018). I thank Jitka Špeciánová and the participants of the conference Philosophy between Past and Future (SKKU Seoul, 2017) for many helpful comments.

\section{REFERENCES}

Achen, C. H., \& Bartels, L. M. (2016). Democracy for Realists: Why Elections Do Not Produce Responsive Government. Princeton, NJ: Princeton University Press.

Arrow, K. (1951). Social Choice and Individual Values. New Haven, New York, London: J. Wiley / Chapman \& Hall.

Ashraf, N., Camerer, C. F., \& Loewenstein, G. (2005). Adam Smith, Behavioral Economist. Journal of Economic Perspectives, 19 (3), 131-145. doi: 10.1257/089533005774357897

Becker, G. S. (1978). The Economic Approach to Human Behavior. Chicago: University of Chicago Press.

Dowding, K. (2005). Is it Rational to Vote? Five Types of Answer and a Suggestion. The British Journal of Politics and International Relations, 7 (3), 442-459. doi: 10.1111/j.1467-856X.2005.00188.x

Downs, A. (1957). An Economic Theory of Democracy. Boston: Harper and Row.

Düppe, T. (2011). The Making of the Economy: A Phenomenology of Economic Science. Plymouth: Lexington Books.

Friedman, M. (1953). Methodology of Positive Economics. In M. Friedman, Essays in Positive Economics (3-16, 30-43). Chicago: University of Chicago Press.

Green, D. P., \& Shapiro, I. (1994). Pathologies of Rational Choice Theory: a Critique of Applications in Political Science. New Haven, Conn.: Yale University Press. 
Knudsen, C. (2004). Alfred Schütz, Austrian Economists and the Knowledge Problem. Rationality and Society, 16 (1), 45-89. doi: 10.1177/1043463104036622

Kuhn, T. S. (1996). The Structure of Scientific Revolutions. Chicago: University of Chicago Press.

Lazear, E. P. (2000). Economic Imperialism. The Quarterly Journal of Economics, 115 (1), 99-146. doi: $10.2307 / 2586936$

Prendergast, C. (1986). Alfred Schütz and the Austrian School of Economics. American Journal of Sociology, 92 (1), 1-26.

Robbins, L. (2007). An Essay on the Nature and Significance of Economic Science. Auburn, Al.: Ludwig von Mises Institute.

Rosenberg, A. (1994). Economics - Mathematical Politics or Science of Diminishing Returns? Chicago: University of Chicago Press.

Rosenberg, A. (2005). Lessons from Biology for Philosophy of the Human Sciences. Philosophy of the Social Sciences, 35 (1), 3-19. doi: 10.1177/0048393104271921

Schütz, A. (1972). The Phenomenology of the Social World. Evanston, Ill.: Northwestern University Press.

Schütz, A. (1974a). Common-sense and Scientific Interpretation of Human Action. In M. Natanson (Ed.), Collected Papers, Vol. 1: The Problem of Social Reality (1-47). Berlin: Springer.

Schütz, A. (1974b). On Multiple Realities. In M. Natanson (Ed.), Collected Papers, Vol. 1: The Problem of Social Reality (207-259). Berlin: Springer.

Schütz, A. (1975). The Problem of Transcendental Intersubjectivity in Husserl. In I. Schütz (Ed.), Collected Papers, Vol. 3: Studies in Phenomenological Philosophy (51-91). Berlin: Springer.

Schütz, A. (1976a). Dimensions of the Social World. In A. Brodersen (Ed.), Collected Papers, Vol. 2: Studies in Social Theory (20-63). Berlin: Springer.

Schütz, A. (1976b). The Problem of Rationality in the Social World. In A. Brodersen (Ed.), Collected Papers, Vol. 2: Studies in Social Theory (64-88). Berlin: Springer.

Stigler, G. J. (1983). Nobel Lecture: The Process and Progress of Economics. Journal of Political Economy, 91 (4), 529-545. doi: 10.2307/1831067 